\title{
Cutting propagation of Quercus acutissima clones after rejuvenation through serial grafting
}

\author{
HK Moon ${ }^{1}$, JS Yi ${ }^{2}$ \\ 1 Institute of Forest Genetics, Forestry Administration, Suwon, 441-350; \\ ${ }^{2}$ Department of Forestry, College of Forestry, Kangweon National University, \\ Chooncheon, 200-701, Republic of Korea
}

\begin{abstract}
Summary - Vegetative propagation of 34- to 67-year-old Quercus acutissima trees was successfully achieved from rooted cuttings. Semi-hardwood ramets which were obtained from the clones established through grafting twice onto the 2-year-old rootstocks showed $60 \%$ rooting (ranging from $20 \%$ to $100 \%$ ). After grafting only once, average rooting frequency was $11 \%$ (ranging from 0 to $34 \%$ ) using cuttings dipped in $500 \mathrm{ppm}$ indole-butyric acid (IBA) solution. The rooting medium consisted of equal volumes of peatmoss and perlite. Cuttings were watered by intermittent mist and grown in the greenhouse at $25 \pm 3{ }^{\circ} \mathrm{C}$ for more than 5 weeks. For rooting, there was no significant difference between ortet age but marked differences were observed among the clones. Although most of the rooted cuttings did not sprout new buds in the current year, they usually produced slowly-growing buds and/or revealed plagiotropic growth at the following year.
\end{abstract}

Quercus acutissima / rejuvenation / serial grafting / semi-hardwood cutting

Résumé - Bouturage de Quercus acutissima après greffage en cascade. La multiplication végétative de Quercus acutissima âgés de 34 et 67 ans a été réalisée avec succès. Deux générations successives de greffage sur des porte-greffes de 2 ans ont permis d'obtenir des boutures semiligneuses manifestant un taux d'enracinement de $60 \%$ (variation totale de $20 \%$ à 100\%). Après la première génération de greffes le taux d'enracinement n'était que de $11 \%(0 \%$ à $34 \%)$; les boutures étaient trempées dans de l'acide indolbutyrique $500 \mathrm{ppm}$, le substrat était constitué d'un mélange en quantités égales de tourbe et de perlite. Les boutures étaient élevées sous mist intermittent dans une serre à $25^{\circ} \mathrm{C}$ (plus ou moins $3^{\circ} \mathrm{C}$ ) pendant 5 semaines. L'âge de l'ortet n'avait pas d'effet sur les taux d'enracinement; par contre des variations importantes entre clones ont été observées. Bien que la plupart des boutures n'aient pas débourré durant l'année de l'enracinement, elles produisirent des petites pousses l'année suivante, qui étaient dans certains cas plagiotropiques.

Quercus acutissima /rejuvénilisation / greffage en cascade / bouture semi-ligneuse 


\section{INTRODUCTION}

In research and usage, little attention has been paid to hardwoods partly due to the forestry policy which focused on conifers and our habitual ways of thinking. Among hardwoods, oaks were considered just for usage such as fuel, tool handles, small furniture, acorns and timber for black forest mushroom (Lentinus edodes (Berk) Sing). However, the consumption of oak timber has gradually increased along with the development of wood-processing techniques and the diversity of wood demands (Lee et al, 1989).

At the Institute of Forest Genetics in Suwon, Korea, an Oak Improvement Project which aimed at clonal conservation of selected trees and the development of an efficient propagation method were started in 1982. However, grafting incompatibility caused considerable loss of clones in the clone bank which was established in 1984 . Two methods are now highly recommended for oak propagation from rooted cutting and/or in vitro culture to overcome the obstacles. Although some successes have been reported in vegetative propagation whether by rooted cuttings or by in vitro culture (Spethmann, 1985; Manzanera and Pardos, 1990), oaks are still difficult to root compared with other forest trees (Skinner, 1953; Flemer, 1962). Previous studies have revealed the possibility of asexual multiplication of juvenile oak trees by semi-hardwood cuttings and tissue culture (Moon et al, 1987, 1988). However, the same propagation method was not successful with adult oak trees. The method described for effective rejuvenation may open the way for mass-propagation of oak species and was obtained through serial grafting of $Q$ acutissima clones. This is the first report on the rejuvenation of this species using repeated grafting.

\section{MATERIALS AND METHODS}

\section{Experiment 1}

Eight clones of $Q$ acutissima plus trees, 34- to 62 -years-old, provided the first ramets for serial grafting followed by rooted cuttings. Scions, collected in February 1988, were wrapped in plastic bags containing moist cotton and stored in a refrigerator at $4{ }^{\circ} \mathrm{C}$. Scions having 2 or 3 buds were grafted onto the 2-year-old rootstocks of the same plus trees in March 1988 and maintained in the greenhouse. In July 1988, semihardwood cuttings were taken from the shoots of the growing scions. The second grafting (using ramets from the first grafts in 1988) and semi-hardwood cuttings (using ramets from the second grafts in 1989) followed by the procedures of 1988 were carried out in March 1989 and July of the same year, respectively. Cuttings $10-12 \mathrm{~cm}$ in length, with 2 or 3 leaves were used. The proximal ends of cuttings were dipped into $500 \mathrm{ppm}$ indolebutyric acid (IBA) solution for $3 \mathrm{~s}$ prior to being applied with a Captan and talc mixture. The rooting medium was formulated by mixing equal volumes of peatmoss and perlite then sterilized by autoclaving at $121^{\circ} \mathrm{C}$. Cuttings were watered with intermittent mist and maintained in a greenhouse (where solar screens were installed to give $30 \%$ shade) at $25 \pm 3^{\circ} \mathrm{C}$ for up to 5 weeks. Each clone provided 4-44 cuttings. After transplantation of the rooted cuttings into vinyl pots (height $\mathrm{x}$ width $=$ $18 \times 7 \mathrm{~cm}$ ) containing an artificial soil mix, observations were made periodically during the winter to investigate survival and growth.

\section{Experiment 2}

Because the rootability of the cuttings taken from second grafts was significantly increased, further experiments were conducted using just the second grafts. For experiment 2, the first and subsequent graftings were done in March 1989 and March 1990, respectively. A total of 22 clones grafted twice were used for semihardwood cuttings in July 1990 (table I). Cutting procedures were followed by the methods described for experiment 1. 


\section{RESULTS AND DISCUSSION}

The rooting percentage varied among the clones and according to grafting times (fig 1). After the first graft in experiment 1 , Kyonggi (KG) clone 5 showed $34 \%$ of rooting but the average rooting percentage of all 8 clones was $11 \%$; which implies that the physiological age of ortets (34-62 yr) was not changed by a single grafting. After the second graft, however, Chunbuk (CB) clones 17 and 30 showed rootabilities of 64 and $93 \%$, respectively. This suggested that the scions may have been rejuvenated by the juvenile rootstocks (Doorenbos, 1954; Franclet, 1983; Siniscalco and Pavolettoni, 1988).

The age of the ortet has been reported as being one of the important factors for successful vegetative propagation (Isebrands and Crow, 1985). The results from both experiments, however, showed no recognizable differences in rootability by the tested ages after grafting. Serial grafting increased the rooting frequency of the cuttings derived from $\mathrm{KG}$ clone 5 which was 62-years-old, whereas $\mathrm{CB}$ clone 41 and Chungnam (CN) clones 1 , both were 36-year-old, did not show such marked improvement. These results suggest that clonal differences are critical for efficient vegetative propagation of this species. When the cuttings of 60-year-old Quercus robur and Quercus petraea were incorporated, varied rootability $(0 \%-40 \%)$ was observed (Spethmann, 1985).

Rejuvenation which could be obtained by serial grafting to young root stocks seems to be an essential step for efficient asexual propagation from adult trees (Hackett, 1985). Doorenbos (1954) and Paton et al (1970) also reported similar results using ivy and eucalypts, respectively. Moon et al (1988) reported successful rooting from almost all the ramets of $Q$ acutissima obtained from the second grafts of
Table I. Rooting of cuttings of $Q$ acutissima plus tree clones which were rejuvenated by repeated grafting onto the 2-year-old rootstocks.

\begin{tabular}{ll}
\hline Clones & $\begin{array}{l}\text { Ortet } \\
\text { age } \\
(y r)\end{array}$ \\
& cuttings rooted percent-
\end{tabular}

$\begin{array}{crrrr}\text { Chunbuk (CB) } & & & \\ 2 & 36 & 8 & 3 & 37.5 \\ 3 & 35 & 21 & 11 & 52.4 \\ 5 & 36 & 17 & 16 & 94.1 \\ 8 & 34 & 3 & 1 & 33.3 \\ 9 & 36 & 15 & 10 & 66.7 \\ 11 & 35 & 15 & 11 & 73.3 \\ 18 & 34 & 18 & 15 & 83.3 \\ 20 & 36 & 11 & 6 & 54.5 \\ 23 & 35 & 10 & 8 & 80.0 \\ 25 & 35 & 17 & 11 & 64.7 \\ 26 & 34 & 22 & 18 & 81.8 \\ 29 & 34 & 3 & 3 & 100 \\ 36 & 35 & 19 & 16 & 84.2\end{array}$

Chungnam (CN)

$\begin{array}{rrrrr}2 & 36 & 14 & 7 & 50.0 \\ 3 & 38 & 20 & 14 & 70.0 \\ 9 & 39 & 19 & 11 & 57.9 \\ 11 & 38 & 11 & 5 & 35.9 \\ 14 & 34 & 14 & 5 & 35.9 \\ 15 & 34 & 5 & 1 & 20.0\end{array}$

Kyonggi ( $\mathrm{KG}$ )

$\begin{array}{rrrrr}3 & 67 & 45 & 10 & 22.2 \\ 8 & 56 & 7 & 7 & 100\end{array}$

Kyongbuk (KB)

$\begin{array}{lllll}3 & 50 & 23 & 14 & 60.9\end{array}$

Total of

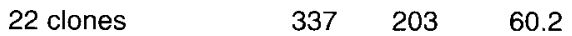

a Represents the age of mother trees at the time of cutting propagation.

the 2-year-old rootstocks. Although high concentrations of rooting substances were applied to ramets, direct cuttings from adult branches of the same species did not root at all. These investigations strongly 


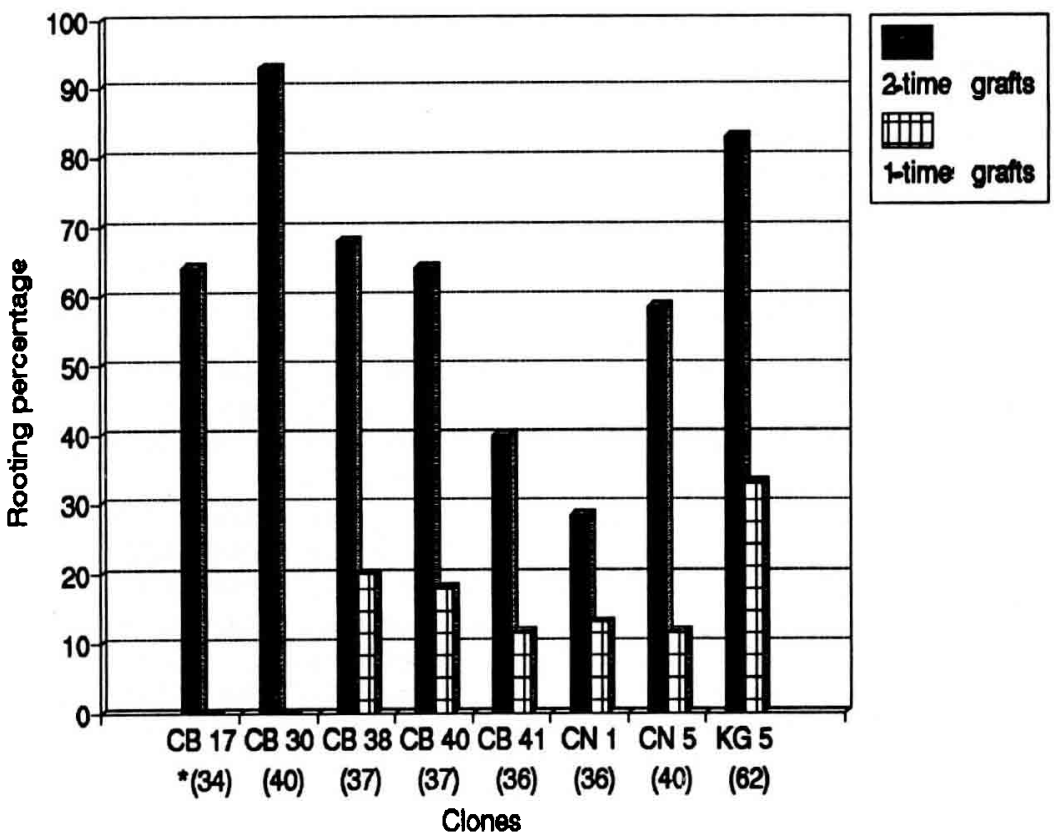

Fig 1. The effect of serial grafting on rooting of 8 clones of $Q$ acutissima. * Represents the age of mother trees at the time of cutting propagation.

suggest that the rooting enhancement shown in figure 1 and table I resulted from rejuvenation by serial grafting onto juvenile understocks. The results obtained from the rooting frequencies of the plus tree clones, allowed the clones tested to be classified into 4 groups: 1) very easy to root (CB 5 , CB 29 and $K G$ 8); 2) easy to root (CB 9, CB 11, CB 18, CB23, CB26, CB36, CN 3 and KB 3); 3) difficult to root (CB 3, CB 20, $C N 2, C N 9$ and $C N$ 11) and 4) very difficult to root (CB 2, CB 8, CN 14, CN 15 and $K G$ 3). Siniscalco and Pavolettoni (1988) reported that rootability of eucalypt cuttings was significantly increased by repeated grafting on to juvenile rootstocks, more than 6 times, and also inferred that rejuvenation could be gradually improved. In this study, however, we did not graft more than twice because the rootability reached higher than $60 \%$.

Rooted cuttings usually developed 1 or 2 primary roots. Relatively high number of ramets produced a callus or callus with roots at the basal end of the shoot. This type of plant eventually died after transplanting into the artificial soil mix. Normal rooted cuttings were kept in the greenhouse during the first winter. Most of the rooted cuttings did not sprout new buds during the current year; they usually produced slowly-growing buds and/or revealed plagiotropic growth at the following year.

Recent advances in in vitro culture systems provide another possible approach for rejuvenation of woody plants. Serial subculture onto the media containing cy- 
tokinins revealed rejuvenation of the mature explants (Franclet, 1983; Hackett, 1985; Fouret et al, 1986; Pierik, 1990). We also observed that 60-year-old $Q$ acutissima could be propagated effectively when the explants were cultured in vitro on a medium for multiple branching (data are not shown). In order to develop a reliable rejuvenation system and/or certify the status of rejuvenation, more extensive studies on morphological, physiological, biochemical and molecular biological aspects are being undertaken.

\section{ACKNOWLEDGMENTS}

We are indebted to Dr Sung Ho Son for reviewing the manuscript. This study was financially supported by a grant from the Korean Science and Engineering Foundation (KOSEF).

\section{REFERENCES}

Doorenbos J (1954) Rejuvenation of Hedera helix in graft combination. Proc KI Ned Akad Wet Ser C Biol Med Sci 57, 99-102

Flemer W (1962) The vegetative propagation of oaks. In Plant Propag Soc Proc 12, 168-171

Fouret $Y$, Arnaud $Y$, Larrieu $C$, Miginiac $E$ (1986) Sequoia sempervirens as an in vitro rejuvenation model. NZJ For Sci 16, 319-327

Franclet A (1983) Rejuvenation: theory and practical experiences in clonal silviculture. In: Clonal Forestry: its Impact on Tree Improvement and our Future Forests (Zsuffa L, Rauter RM Yeatman CW, eds), Can Tree Improvement Assoc, Proceeding of the 19th Meeting, Part 2, Toronto, 96-134
Hackett WP (1985) Juvenility, maturation, and rejuvenation in woody plants. Hortic Rev 7 , 109-155

Isebrands JG, Crow TR (1985) Techniques for rooting juvenile softwood cuttings of northern red oak. Proceeding of the 5th Central Hardwood Forestry Conference, Univ of IL, Urbana-Champaign, 228-233

Lee DK, Lee KJ, Suh MH, Woo SY, Kim DW (1989) Propagation and establishment of oak species. In: Studies on the Use and Development of Oak Resources (Administration of Science and Technology, ed) For Res Inst Korea 141-211

Manzanera JA, Pardos JA (1990) Micropropagation of juvenile and adult Quercus suber. Plant Cell Tissue Organ Cult 21, 1-8

Moon HK, Kim JH, Park Jl (1987) Position effect of axillary buds on shoot multiplication and rooting in bud culture of Quercus acutissima. $J$ Kor For Soc 76, 370-375

Moon HK, Park MH, Lee KY, Park YH (1988) Rooted cuttings using juvenile semi-hard wood of some useful oaks and rooted cuttings of grafted seedlings of $Q$ acutissima plus tree. Res Rep Inst For Genet Korea 24, 42-46

Paton DM, Willing RR, Nicholls W, Pryor LD (1970) Rooting of stem cuttings of Eucalyptus: a rooting inhibitor in adult tissues. Aust $J$ Bot 18, 175-183

Pierik RLM (1990) Rejuvenation and micropropagation. IAPTC Newslett No 62, 11-21

Siniscalco C, Pavolettoni L (1988) Rejuvenation of Eucalyptus $\times$ Trabutii by successive grafting. Acta Hortic Wageningen 227, 98-100

Skinner HT (1953) Propagation of oaks. Am Nurseryman 98, 63-69

Spethmann W (1985) Mass propagation of oak by cuttings. International Plant Propagator's Society Annual Conference 3-6, Sept, 1985, Univ of Essex, Colchester (poster presentation) 